\title{
SISTEM INFORMASI PENGELOLAAN DATA VOLUME SAMPAH TPA CAHAYA KENCANA KAB. BANJAR
}

\author{
Aulia Rizky Muhammad Hendrik Noor Asegaff ${ }^{1)}$, M Dedy Rosyadi ${ }^{2)}$, Budi Ramadhani ${ }^{3)}$ \\ ${ }^{1}$ Fakultas Teknologi Informasi, Universitas Islam Kalimantan Muhammad Arsyad Al Banjari (Aulia \\ Rizky Muhammad Hendrik Noor Asegaff) \\ email : aulia.rizky.m.h.n.a@gmail.com \\ ${ }^{2}$ Fakultas Teknologi Informasi, Universitas Islam Kalimantan Muhammad Arsyad Al Banjari (M Dedy \\ Rosyadi) \\ email : dedy.rosyadi@gmail.com \\ ${ }^{3}$ Fakultas Teknologi Informasi, Universitas Islam Kalimantan Muhammad Arsyad Al Banjari (Budi \\ Ramadhani) \\ email : budiramadhani99@gmail.com
}

\begin{abstract}
Abstrak
Pada observasi yang telah kami lakukan di TPA Cahaya Kencana, aktifitas pencatatan data sampah yang masuk ke TPA Cahaya Kencana hanya dilakukan dengan mencatat pada buku tulis dan kemudian data tersebut dimasukan lagi menggunakan aplikasi Microsoft Excel dengan membuat kolom table yang sederhana. Hal tersebut menyulitkan dalam mencari hasil rekapitulasi data volume sampah untuk jangka panjang sebagai arsip laporan sebagai bahan analisis pengembangan kinerja TPA Cahaya Kencana. Dari permasalahan tersebut peneliti ingin mengembangkan Sistem Informasi pengelolaan data volume sampah berbasis web yang dapat membantu TPA Cahaya Kencana dalam mengelola data volume sampah. Tahapan yang dilakukan pada pengembangan sistem informasi ini menggunakan model SDLC (System Development Life Cycle). Model SDLC merupakan suatu metodologi yang biasa digunakan oleh para developer dalam melakukan pengembangan dan pembuatan sistem informasi. Dalam pelaksanaannya Model SDLC mempunyai beberapa tahapan yang harus dilakukan yaitu : analisis, perancangan, pembuatan, implementasi, pengujian, dan pemeliharaan.
\end{abstract}

Kata Kunci : Sistem Informasi, data, volume, sampah, SDLC

\section{PENDAHULUAN}

TPA Cahaya Kencana merupakan TPA yang terdapat di Desa Padang Panjang Kab. Banjar dengan luas $16 \mathrm{Ha}$ yang saat ini aktif melayani Sembilan (9) Kecamatan di wilayah Kab. Banjar yaitu : Martapura Kota, Martapura Barat, Martapura Timur, Sungai Tabuk, Gambut, Karang Intan, Kertak Hanyar, Astambul dan Aranio. Hampir setiap harinya TPA Cahaya Kencana menerima hasil sampah dari TPS dari setiap kecamatan dengan menggunakan armada pengangkut sampah. Tugas staff/pegawai TPA Cahaya kencana yaitu melakukan pencatatan terhadap sampah yang masuk.

Berdasarkan kegiatan yang telah dijelaskan permasalahan yang ditemukan adalah pada aktivitas pencatatan data sampah yang masuk ke TPA Cahaya Kencana hanya dilakukan dengan mencatat jumlah sampah sesuai dengan hasil timbangan pada buku tulis dan kemudian data tersebut dimasukan lagi menggunakan aplikasi Ms. Excel dengan membuat kolom table yang sederhana. Kegiatan pencatatan ini dilakukan secara berulang setiap harinya dan file disimpan pada file yang telah dibuat sesuai dengan nama bulan sehingga untuk mendapatkan hasil rekapitulasi data volume sampah untuk jangka panjang memerlukan proses yang lebih lama dengan membuat lagi file baru untuk menjumlahkan data volume sampah yang masuk sesuai dengan bulan atau tahun yang akan di buat hasil laporannya.

Melalui sistem informasi yang akan dibuat pada penelitian ini, staff/pegawai lapangan yang bertugas dapat mengetahui informasi data melalui informasi yang tersedia 
pada sistem. Sistem informasi ini dibuat berbasis Web untuk memudahkan para staff/pegawai dalam melakukan pencatatan data volume sampah yang masuk ke TPA Cahaya Kencana sampai kepada tahap pelaporan data rekapitulasi yang bisa didapatkan dengan cepat melalui Sistem Informasi sesuai dengan keperluan data yang diinginkan.

\section{METODE PENELITIAN}

Teknik analisis data yang digunakan dalam penelitian ini menggunakan SDLC (System Development Life Cycle) dengan prosedur pengembangan model Waterfall. Model ini melakukan pendekatan secara sistematis dan urutan mulai dari level kebutuhan sistem kemudian menuju ketahap analisis data, perancangan, pembuatan, pengujian, implementasi, dan pemeliharaan sistem.

Berikut ini adalah tahapan yang akan dilakukan dalam proses penelitian :

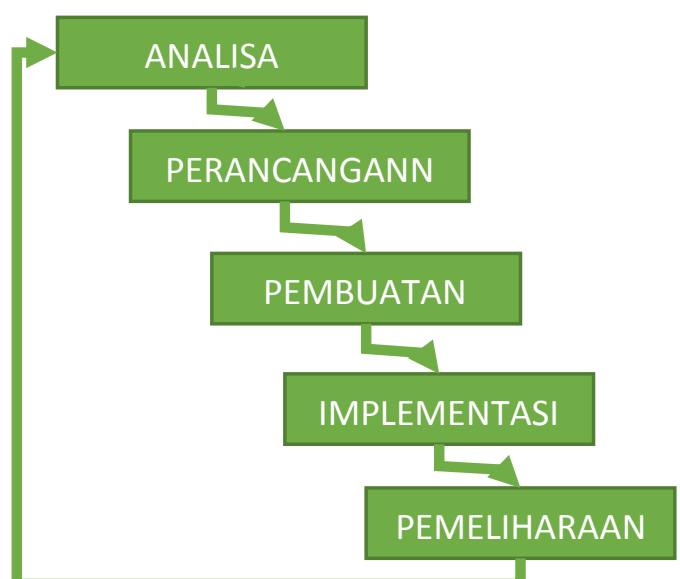

Gambar 2.1. Tahapan Pengembangan Sistem

Dalam melakukan penelitian ini perlu untuk mendapatkan data dan informasi, maka metode yang digunakan dalam proses pengumpulan data adalah sebagai berikut :

1. Metode Wawancara

2. Metode Observasi

\subsection{Kerangka Pemikiran}

Dalam melakukan penelitian ini diperlukan perencanaan yang baik dari awal penelitian dimulai sampai aplikasi bisa diimplementasikan. Berikut urutan Kerangka Pemikiran pada penelitian ini :

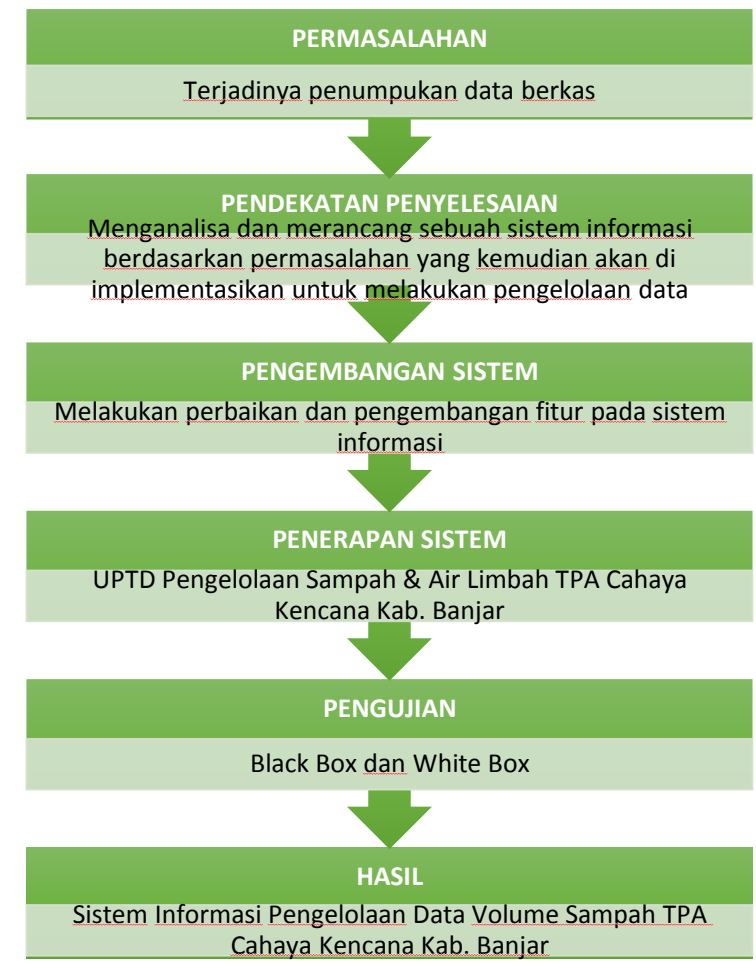

Gambar 2.2. Kerangka Pemikiran

\subsection{Rancangan Sistem}

Berikut adalah Diagram Konteks yang menggambarkan isi/konteks serta batasanbatasan system yang akan dikembangkan.

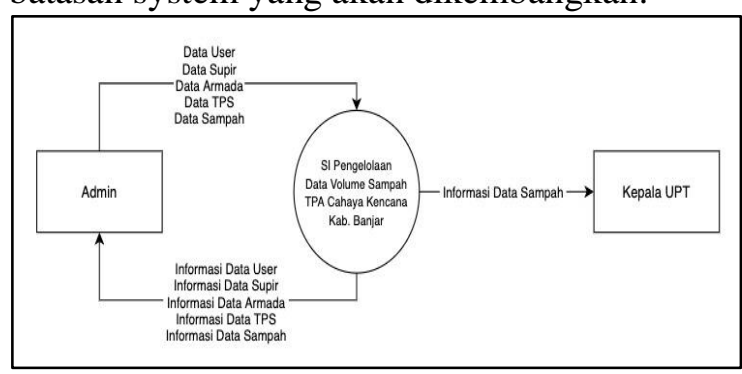

Gambar 2.3. Diagram Konteks

\section{HASIL DAN PEMBAHASAN}

\subsection{Antarmuka Aplikasi}

Antarmuka aplikasi adalah faktor penting yang harus diperhatikan dalam pembuatan dan pengembangan sebuah aplikasi karena semua pengguna yang terlibat dalam aplikasi itu pasti akan berhadapan langsung dengan semua halaman yang akan di akses pada aplikasi yang digunakan, oleh karena itu antarmuka dalam sebuah aplikasi harus di rancang dengan sebaik mungkin dan kemudian dibuat sesuai dengan rancangan untuk mempermudah pada saat menggunakan aplikasi. Pada aplikasi ini terdapat beberapa 
form yang digunakan untuk melakukan pengelolaan dan pengolahan data. Adapun form yang digunakan pada aplikasi ini, yaitu :

a. Halaman login

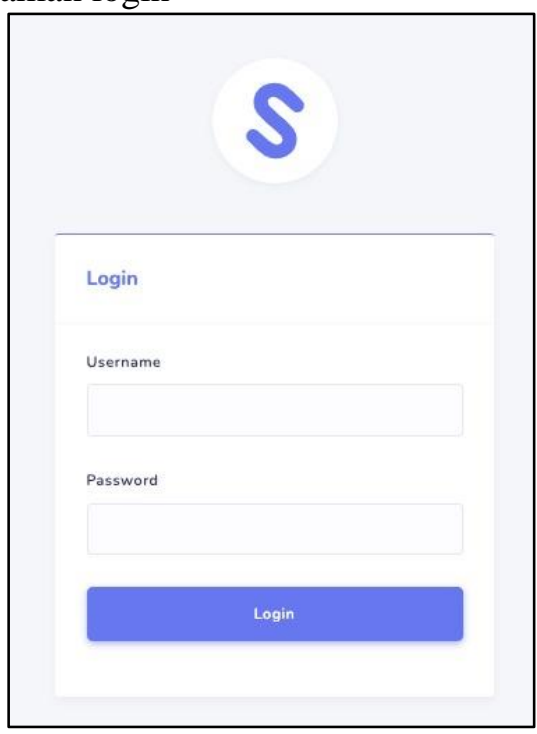

Gambar 3. 1 Login Aplikasi

b. Halaman Dashboard

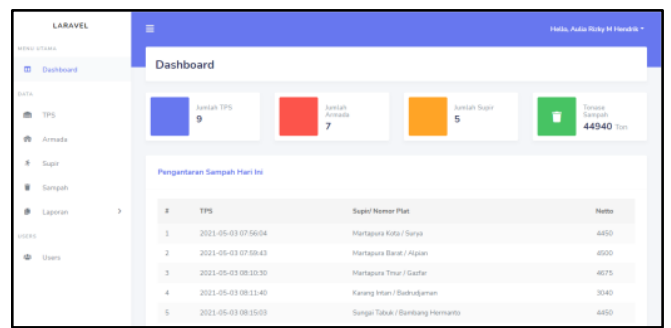

Gambar 3. 2 Halaman Dashboard

c. Halaman Data TPS

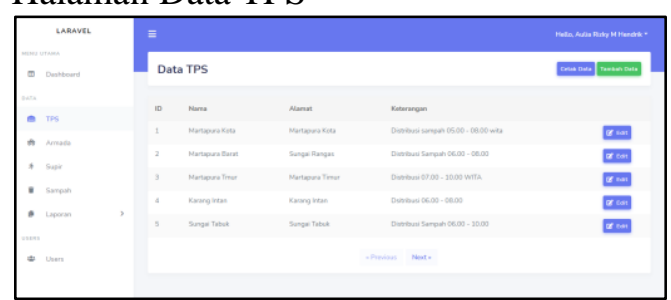

Gambar 3. 3 Halaman Data TPS

d. Halaman Data Armada

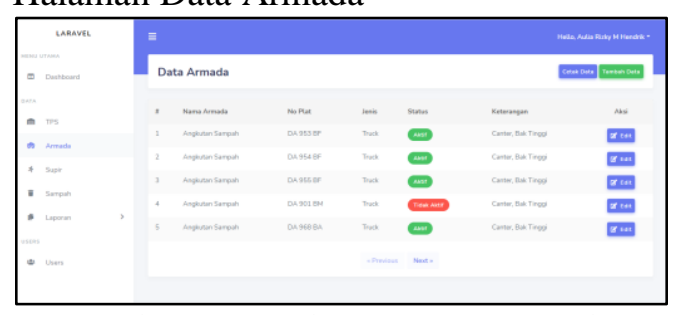

Gambar 3. 4 Halaman Data Armada e. Halaman Data Supir

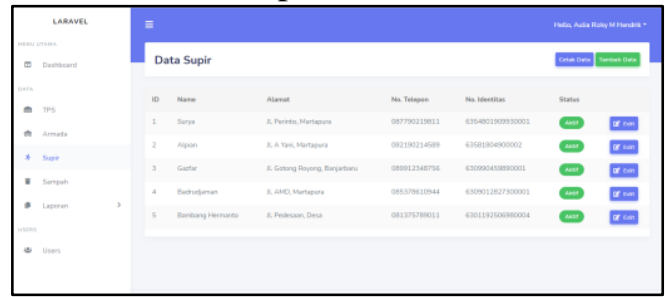

Gambar 3. 5 Halaman Data Supir

f. Halaman Data Sampah

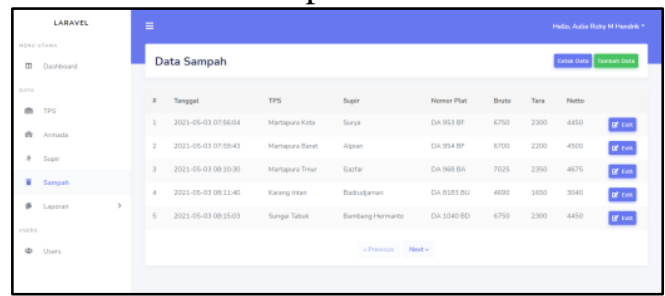

Gambar 3. 6 Halaman Data Sampah

\subsection{Implementasi}

Hasil dari penelitian ini adalah berupa Sistem Informasi Pengelolaan Data Volume Sampah yang akan diimplementasikan di TPA Cahaya Kencana Kabupaten Banjar. Sistem informasi ini akan digunakan oleh pegawai yang bertindak sebagai operator yang menjalankan sistem yang dibuat ini. Sistem informasi ini dibuat untuk membantu petugas / operator dalam merekap jumlah sampah yang masuk ke TPA. Menyelaraskan antara data TPS, Armada dan Supir dengan jumlah volume sampah yang masuk setiap harinya sehingga memudahkan dalam pembuatan laporan yang perlu disampaikan ke pimpinan setiap bulannya. Data-data yang dilaporkan antara lain :

a. Laporan data TPS

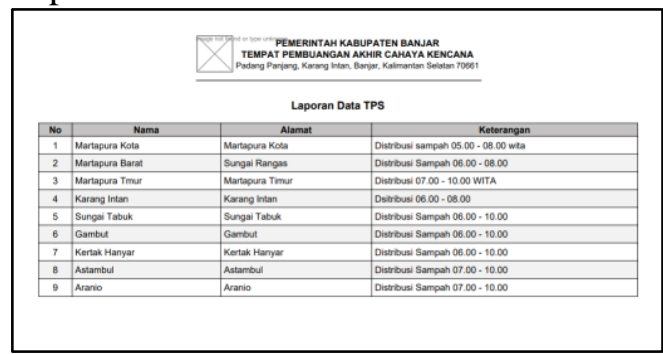

Gambar 3. 7 Laporan Data TPS 
b. Laporan Data Armada

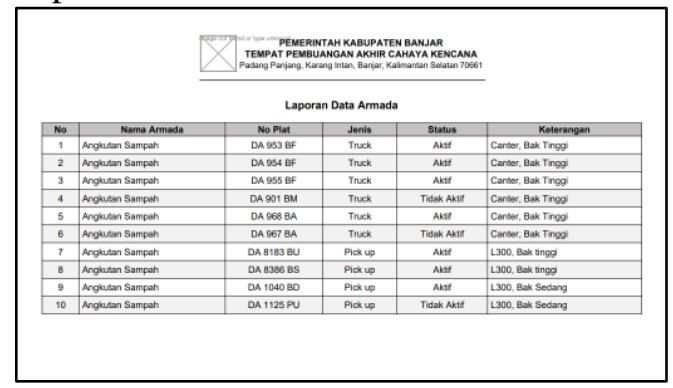

Gambar 3. 8 Laporan Data Armada

c. Laporan Data Supir

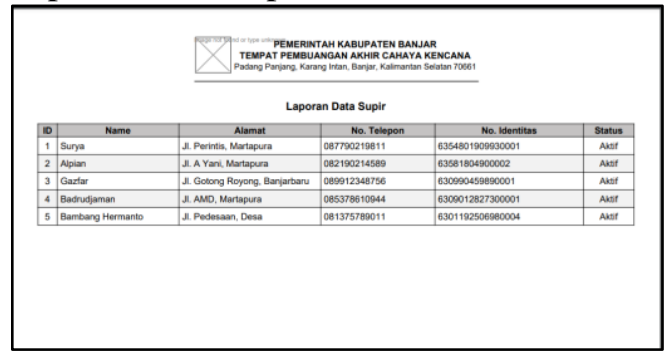

Gambar 3. 9 Laporan Data Supir

d. Laporan Data Sampah Masuk

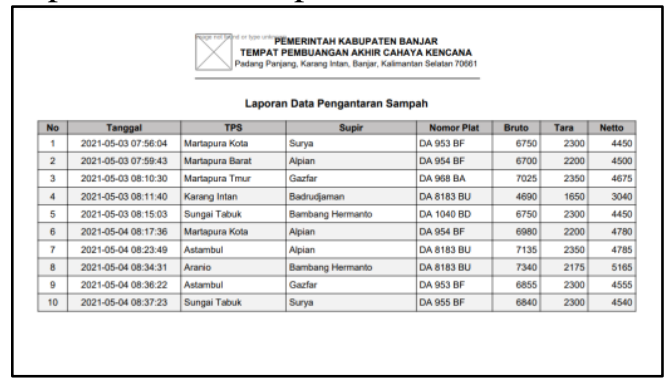

Gambar 3. 10 Laporan Data Sampah

e. Laporan Data Pengantaran Sampah

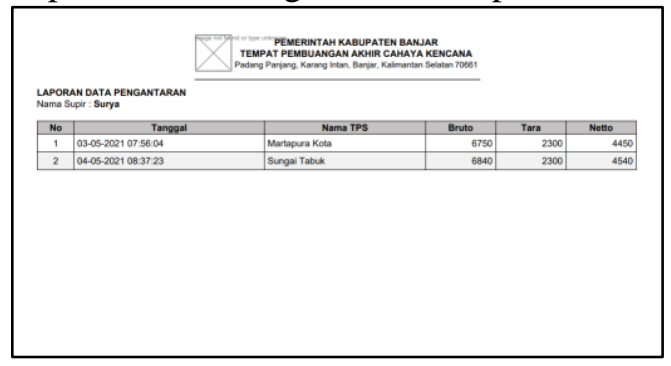

Gambar 3. 11 Laporan Data Pengantaran Sampah f. Laporan Jumlah Sampah TPS

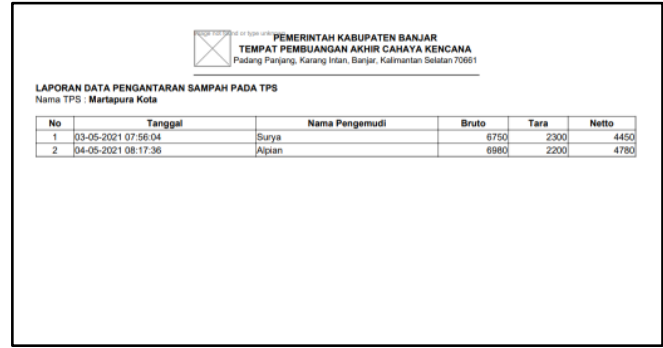

Gambar 3. 12 Laporan Jumlah Sampah TPS

Laporan yang dihasilkan tersebut merupakan hasil dari pemprosesan data sampah masuk setiap harinya yang diinputkan oleh operator. Dari laporan tersebut nantinya dapat digunakan sebagai data analisis perkembangan sampah di TPA Cahaya Kencana yang membantu dalam pengambilan keputusan.

\section{KESIMPULAN}

Kesimpulan yang didapat dari penelitian ini yaitu :

1. Pembuatan Sistem Informasi Pengelolaan Data Volume Sampah telah berhasil dan dapat digunakan oleh pegawai / operator di TPA Cahaya Kencana.

2. Aplikasi yang dibuat untuk mempermudah pegawai / operator dalam pengelolaan dan pengolahan data volume sampah yang masuk di TPA Cahaya Kencana.

3. Dengan aplikasi ini pembuatan dan pencarian laporan menjadi lebih cepat, tepat dan akurat. Laporan tersebut dapat menjadi data analisis dalam pengembangan TPA kedepannya.

\section{DAFTAR PUSTAKA}

[1] Abdullah, R. (2017). Membuat Aplikasi Point Of Sales dengan Laravel dan Ajax. PT Elex Media Komputindo.

[2] Anggraeni, E. Y., \& Irviani, R. (2017). Pengantar Sistem Informasi. Penerbit Andi.

[3] Jannah, M., Sarwadi, \& Creative, C. (2019). Mahir Bahasa Pemrograman PHP. PT Elex Media Komputindo. 
[4] Karisma, Y., Muthi'ah, A., \& Esabella, S. (2020, Agustus). Rancang Bangun Aplikasi Pengolahan Data Sampah Pada Dinas Lingkungan Hidup Kab. Sumbawa Berbasis WEB. JINTEKS (Jurnal Informatika Teknologi dan Sains), 2.

[5] Magdalena, H., Santoso, H., \& Rochmayani, K. (2019, Desember). Sistem Retribusi Sampah Berbasis Web untuk Optimalisasi Kinerja Bidang Pengelolaan Sampah. Cogito Smart Journal, 5.

[6] Mahyudin, R. P. (2017). Kajian Permasalahan Pengelolaan Sampah dan Dampak Lingkungan di TPA (Tempat Pemrosesan Akhir). Jukung Jurnal Teknik Lingkungan, 3, 66-74.

[7] Peraturan Bupati Banjar Nomor 53. (2014). Uraian Tugas Unit Pelaksana Teknis Pengelolaan Sampah \& Air Limbah.

[8] Undang-Undang Republik Indonesia Nomor 18. (2008). Pengelolaan Sampah.

[9] Virdiandry, \& Putratama, S. (2018). Pemrograman Web Dengan Menggunakan PHP dan Framework Codeigniter. Deepublish. 